\title{
Relationship Of Magic Mushroom Literation As A Drug With Abuse It's Use As A Hallucination
}

\author{
Yuri Rahayu ${ }^{*}$,Andi Riyanto ${ }^{2}$,Agung Wibowo ${ }^{3}$ \\ ${ }^{*}, 2,3$ Universitas Bina Sarana Informatika,Indonesia \\ *e-mail: ${ }^{* 1}$ yuri.yru@bsi.ac.id; ${ }^{2}$ andiryantoubs@gmail.com, ${ }^{3}$ agung@gmail.com
}

\begin{abstract}
Some cases consuming Magic mushroom resulting in death and behave strangelinto concerns. Literacy or knowledge of the dangers of this toxic fungus needs to be socialized so that communities especiallyteenagers did not attempt to try to thrill to get satisfaction because of the nature of the hallucinations caused due by consuming Magic Mushroom. Magic mushroom contains the psilocin. This fungus is a narcotic class I in accordance in enactment no. 35 year 2009. The purpose of this study is to know the correlation of literacy about magic mushrooms as a drug with the abuse behavior of teenagers as a Hallucinator in the area of Sukabumi City. The research method used is the quantitative research, with a formula of Association problems. The population of 19.284students with 392 number of sample, it's from high school and equivalent in Sukabumi region without differentiating classes and majors. Based on the results of the test indicate that there is a positive relationship between literacy of students about the magic mushroom with the behavior of misuse as Halusinasinator as evidenced by the value of $0.173>005$. The coefficient of this 0.173 describes a weak relationship.The results of the study provide guidance for the public, especially high school students that by having good knowledge of the dangers of the magic mushroom, students can avoid not consuming them and will maintain good behavior so as not to harm themselves and their environment.
\end{abstract}

\section{Keywords - Literasi Magic Mushroom, Drug and Hallucination}

\section{INTRODUCTION}

S Teens are identical with sensation, a deep curiosity, and they selfactualization are sometimes appearing without any control. Breach of rules is often done only for pleasure. Psychotropic drugs and other addictive substances is a big threat that is difficult to avoid for teenagers. Only faith, devotion, knowledge, and self-motivation, as well as the influence from the surrounding environment, can hinder them to get away from the illegal goods. Creative and innovative ideas not only appeared to yield positive things but also can penetrate into things that are negative. The emergence of Magic Mushroom use as part of the Drug is one of the negative ideas that is very dangerous and threatening the young generation especially teenagers.

IJoASER,Volume 2,Issue 1,March,2019

DOI: 10.33648/ijoaser.v2i1.25

Copyriht: STAI Al-Furqan Makassar,Indonesia

Content License: CC-BY-SA 
The level of personal stress, dependence, and ease to get narcotic drag Indonesia into the dangers of drugs. In Indonesia, the spread of drugs yet increased because of the lack of knowledge of the drug's dangers are still discovered in some areas. Narcotics is identical to the behavior of individuals. Many factors cause a person fellows with narcotics.

Magic Mushroom (cow dung fungus) who grew up in the United States, Mexico, South America, and many other parts of the world contain hallucinogenic compounds psilocybin and psilocin. Psilocybin (4-fosforoksi $\mathrm{N}, \mathrm{N}$-dimethyltryptamine) is a psychoactive compound with mayor found in magic mushrooms, while psilocin (4-hydroxy-N, N-dimethyltryptamine) is a minor. Psilocybin and psilocin along with other compounds in the tryptamine drugs classified narcotics Group I and not used in the medical world, but the addictive substance has the potential for abuse is high[1]. Same is the case with the regulation of the Minister of Health RI No. 342,MENKES/PER/IX/1983 Psilocybin and Psilocin, into one type of Narcotics class I, in compliance with Act No. 35 of the year 2009 about narcotics. Stated that narcotics are substances or drugs derived from plant crops, whether or not a synthesis or semi-synthesis which can cause a decrease or alteration of consciousness, loss of taste, reduce to eliminate pain, and can cause dependence [2].

Several cases of abuse of the use magic mushroom resulting in death and strange behavior occurs in several places. One of these cases overwrites a student UNDIP in Central Java raging and eventually killed due to the hangover after the Magic mushroom party together with his colleagues[3]. In North Sumatra reported by Kompas 15/4/2013 eight children in the village of Janji, Bilah Barat district, LabuhanBatu, North Sumatra, experienced the poisoning due to consuming the mushrooms that grow on cow dung or called the magic mushroom. They should get intensive treatment in a Rantauprapat public hospital after suffering nausea and suffered a lack of fluids in his body[4]. Some of the victims were forced to get an infusion liquid. Magic Mushroom is a fungus that grows on top of animal waste such as cow, horse, even Bull[5]. A study on village Klumprit II where the majority are cattlemen. The growth of the fungus tlethong (Magic Mushroom) in this village are very much, and the villagers Klumprit II do not consume this fungus, knowing the type of and dangers of this fungus[6], The strange event carried out by Karno (48 years) from Kendal had to deal with the authorities due to drunkenness because of consuming Magic Mushroom so that desperate to steal a hearse belonging to the Baitul Hikmah Hospital[7].

Although less common than abuse of marijuana and cocaine, abuse of magic mushroom, peyote cactus, lysergic acid diethylamide (LSD), khat, and volatiles is observed in the United States. Eating wild mushroom is dangerous because misidentification of toxic mushroom as magic mushroom may be fatal. Magic mushroom contains psilocybin and psilocin but major psychedelic action of magic mushroom is due to rapid conversion of psilocybin to psilocin after ingestion [1]

Morphological and toxicological analyses were performed on hallucinogenic mushrooms that are currently circulated in Japan. Scanning electron microscope (SEM) indicated a three-dimensional microstructures in 
the mushrooms. The complementary use of SEM with an optical microscope was effective for observing characteristic tissues, such as basidiomycetes, spores, cystidia and basidia. It thus appears that $P$. cubensis is psilocybinrich, whereas Copelandia is psilocin-rich [8].

Overall estimated prevalence of magic mushroom users in the European Union is much lower than marijuana. However, the prevalence of the time seems to be the same as the Ecstasy among students aged 15-16 years in several countries. Surveys in 12 countries of the European Union show that, among young people aged 15-24 years, magic mushroom user between $1 \%$ to $8 \%$. United Kingdom in the year 2004, nearly 340,000 people aged $16-59$ years using a magic mushroom[9]. Interestingly, the user does not believe that magic mushroom may negatively affect academic performance, physical, mental health and they also do not believe that using magic mushroom can cause addiction[10].

Classification process of poisonous mushroom or not will be easily conducted by learning machine using mining data as one of the ways to extract computer assisted knowledge. Currently, there are three comparisons of the best classification algorithms in data mining, namely: Decision $\mathrm{T}$ ree (C4.5), NaïveBayes and Support Vector Machine (SVM)[11].Knowledge of mushroom classification process using data mining has not been able to answer the presence of abuse of Magic Mushroom, but at least if teenagers have adequate knowledge can keep his behavior so aberrant and not harm the environment and himself.As a comparison material that if a person has sufficient knowledge then behavior will always be maintained properly, so that it will not harm it self or others. Research conducted in the village of Jatigono, sub Lumajang KK Knowledge about the dangers of liquor with the behavior of its users, showed that $46.5 \%$ have knowledge of good (adequate) about the behavior of the use of liquor and $16.3 \%$ the respondents had the knowledge. This condition may be influenced by the level of background teenager education i.e. $67.4 \%$ High School and elementary school as much as $9.3 \%[12]$.

The basic reason for this research because of magic mushroom not so difficult to find and get, no need spend money because this type of mushroom is can easily found at farms area especially in the region of Sukabumi. Ignorance or lack of knowledge of the dangers posed by magic mushroom and curiosity wants to try it out should be prevented by socialization to teens especially high school students or equal because it is very dangerous for health and could decrease the level of intelligence and competence of the user. The purpose this research is to find out the relationship between Literacy about magic mushroom as a drug with the behavior of the Word as Hallucinator against teenagers in the area of Sukabumi. 


\section{METHOD}

The research method used is a quantitative research method, with a formula of Association problems[13]Data collection techniques used through surveys with questionnaires to randomly respondents for obtaining primary data. Standard indicators used are ordinal scale with the "Yes" and "no" answers. The population in this research is the entire19,284 high school students and equal at Sukabumi city [14]Slovin formula obtained by using as much as 392 students as a Sample. The selection of respondents and the school does randomly. The variables used in this study consists of:

1. The free variable (X) is cow dung Fungus Literacy (Magic Mushroom) as a Drug.

2. A bound variable $(\mathrm{Y})$ is the behavior of its use as a Halusinator.

Cow dung Fungus literacy (Magic Mushroom) as a Drug is measure by using a scale of Guttman-type questions in the form of as many as 20 multiple choice questions. This scale will get a firm answer, that is "right" (one) and "wrong" (zero). And for "negative" answer, that is "right" (zero) and "wrong" (one).

Reseults Data Shows :

1. Literacy of someone is known and interpreted with 3 qualitative criteria: good $(76 \%-100 \%)$ of total respondents $15-20$, enough (56\%-75\%) 8-14 > 56\% and less as 0-7 respondents .

2. A bound variable $(\mathrm{Y})$ is the behavior of its use as a Halusinator. is known and interpreted with 3 qualitative criteria: good (76\%-100\%) of total respondents $15-20$, enough (56\%-75\%) 8-14 >56\% and less as $0-7$ respondents [15]

\section{Data Analysis}

Based on the analysis of test data validity of the 392 respondents with 20 questions for the variables $\mathrm{X}$ and $\mathrm{Y}$ with a level of significance of 5\%, state that questions items is valid because of the statementt $t_{\text {hitung }}(\min 1,88188$ ) $>>t_{\text {tabel. }} \quad(1,85955)$. Processing and analysis of data on this research using SPSS application ver. 24 and Statcal.

III. RESULTS 
Based on the results of research on 392 respondents, results of statistical tests showed:

Table 1. Literacy Statistics Test results Magic Mushroom based on Gender and School Origin

\begin{tabular}{|c|c|c|c|c|}
\hline Male & Female & SMUN & SMU-S & SMKN \\
\hline $\begin{array}{c}9,64 \% \\
\text { Not user }\end{array}$ & $\begin{array}{c}98,66 \% \\
\text { Not user }\end{array}$ & $\begin{array}{c}191 \\
\text { Respondent } \\
100 \% \text { Not } \\
\text { user }\end{array}$ & $\begin{array}{c}74 \\
\text { Respondent } \\
97,3 \% \text { Not } \\
\text { User }\end{array}$ & $\begin{array}{c}87 \\
\text { Respondent } \\
100 \% \text { Not } \\
\text { user }\end{array}$ \\
\hline $\begin{array}{c}0,36 \% \\
\text { User }\end{array}$ & $\begin{array}{c}0,89 \% \\
\text { User }\end{array}$ & -- & $2,7 \%$ User & -- \\
\hline
\end{tabular}

The result in table 1 show that: $2.7 \%$ of female students from SMU-S have used Magic Mushroom with a male gender of $1.36 \%$ and a female of $1.34 \%$. This factor can be influenced by the social environment. Where for now in the area of the city of Sukabumi for some high schools the level of discipline is still below the high schools and vocational high schools

Table 2. CriteriaRespondents Literacy as Magic Mushroom as Narcotics

\begin{tabular}{|c|c|c|}
\hline $\begin{array}{l}\text { Criteria value } \\
\text { "Good }\end{array}$ & $\begin{array}{l}\text { Criteria } \\
\text { value“enough" }\end{array}$ & $\begin{array}{c}\text { Criteria value } \\
\text { "less" }\end{array}$ \\
\hline 42 Respondent & 346 Respondent & 4 Respondent \\
\hline $10,71 \%$ & $88,27 \%$ & $1,02 \%$ \\
\hline
\end{tabular}

The results in table 2 show that the literacy of the respondents against fungus cow dung as the majority of the drug is adequate. The results mean that the respondents simply know it and the danger of it contains.

Table. 3 Classification of Literacy as Magic Mushroom and Narcotics

Abuse behavior as hallucinations

\begin{tabular}{|c|c|c|c|c|c|}
\hline \multirow{8}{*}{$\begin{array}{c}\text { Literasi } \\
\text { magic } \\
\text { Mushroom } \\
\text { as } \\
\text { Narcotics }\end{array}$} & & \multicolumn{3}{|c|}{$\begin{array}{c}\text { Abuse behavior as } \\
\text { hallucinations }\end{array}$} & \multirow[t]{2}{*}{ Total } \\
\hline & Information & Less & Enough & Good & \\
\hline & Less & 3 & 0 & 1 & 4 \\
\hline & & $0,76 \%$ & $0 \%$ & $0,26 \%$ & $1,02 \%$ \\
\hline & Enough & 0 & 13 & 333 & 346 \\
\hline & & $0 \%$ & $3,32 \%$ & $84,95 \%$ & $88,27 \%$ \\
\hline & Good & 0 & 0 & 42 & 42 \\
\hline & & $0 \%$ & $0 \%$ & $10,71 \%$ & $10,71 \%$ \\
\hline \multirow{2}{*}{\multicolumn{2}{|c|}{ Total }} & 3 & 13 & 376 & 392 \\
\hline & & 0,76 & $3,32 \%$ & $95,92 \%$ & $100 \%$ \\
\hline
\end{tabular}

The results in table 3 show that the the better the student's knowledge of the dangers of magic mushroom is, the lower the danger of misuse behavior.

IJoASER,Volume 2,Issue 1,March,2019

DOI: 10.33648/ijoaser.v2i1.25

Copyriht: STAI Al-Furqan Makassar,Indonesia

Content License: CC-BY-SA 
Table 4. Spearman 'Rho Test Results Against Literacy as Drugs with Abuse behavior as hallucinations

\begin{tabular}{|c|c|c|c|c|}
\hline \\
\hline & & & $\begin{array}{c}\text { Literasi } \\
\text { magic } \\
\text { Mushroom } \\
\text { as Narcotics }\end{array}$ & $\begin{array}{c}\text { Drug } \\
\text { Abuse } \\
\text { Behavior }\end{array}$ \\
\hline \multirow{6}{*}{$\begin{array}{c}\text { Spearman's } \\
\text { rho }\end{array}$} & \multirow{3}{*}{$\begin{array}{c}\text { Literasi } \\
\text { magic } \\
\text { Mushroom as } \\
\text { Narcotics }\end{array}$} & $\begin{array}{l}\text { Correlation } \\
\text { Coefficient }\end{array}$ & 1.000 & $.173^{* *}$ \\
\hline & & $\begin{array}{l}\text { Sig. } \\
\text { tailed) }\end{array}$ & . & .001 \\
\hline & & $\mathrm{N}$ & 392 & 392 \\
\hline & \multirow{3}{*}{$\begin{array}{l}\text { Abuse } \\
\text { behavior as } \\
\text { hallucinations }\end{array}$} & $\begin{array}{l}\text { Correlation } \\
\text { Coefficient }\end{array}$ & $.173^{* *}$ & 1.000 \\
\hline & & $\begin{array}{l}\text { Sig. } \\
\text { tailed) }\end{array}$ & .001 & \\
\hline & & $\mathrm{N}$ & 392 & 392 \\
\hline
\end{tabular}

Table 4.shows that there is a positive relationship between literacy students on cow dung fungi (magic mushroom) against the abuse behavior of misuse as a Hallucination with a value of $0.05>0.173$. The coefficient of 0.173 shows a weak relationship. These results also show that the higher the literacy student about mushrooms cows dungs as a drug then the better student behavior to abuse it, meaning that with cow dung fungus literacy as one of the types of drugs, respondents will keep his behavior not to use it.

\section{IV.CONCLUSION}

The results of the study provide guidance for the community, especially high school students, that by having good knowledge about the dangers of magic mushrooms, students can avoid not consuming them and will maintain good behavior so as not to endanger themselves and their environment. danger of freeing magic mushrooms one of which can be raised by transmitting associations with school teachers in maternity, can be a teacher of $\mathrm{BP}$ or Walangassass to the height of the understanding of the danger of magic mushrooms.

\section{REFERENCES}

[1] A. Dasgupta, "Abuse of magic Mushroom, Peyote Cactus,LCD, Khat and Volaties," in Critical issues In Alcohol and Rrugs Of Abuse Testing, Haouston, TX United States, -, 2019, pp. 477-494.

[2] UU No.37, Narkotika Golongan 1, 2009. 
[3] N.Setyabudi, “https://news.okezone.com/read/2012/11/17/512/719612 /mabuk-jamur-mushroom-mahasiswa-undip-ngamuk-tewas,"17 November 2012. [Online]. [Accessed 1 September 2018].

[4] Kompas, "Kompas,"makan-magicmushroom-delapananak-keracunan, http://berita.plasa.msn.com /nasional/okezone," 15 April 2013. [Online]. [Accessed 3 September 2018].

[5] www.kaskus.co.id. [Online]. [Accessed 3 September 2018].

[6] A. Taufiq and A. D. Wicaksono, "Sosialisasi Bahaya Narkoba, Psikotropika Dan Zat Aditif (Jamur Tlethong)," Jurnal Inovasi Dan Kewirauahaan, Vols. 4 No.2 Mei 2015 ISSN : 2089-3036, pp. 79-83, 2015.

[7] K. Tsujikawa, T. Kanamari and etc, "Morphological and chemical Analysis of Magic Mushroom in Japan," Forensic Science International, pp. 85-90, 2003.

[8] V. Amsterdam, J. O. A and V. D. Brink, "https://doi.org/10.1016/j.yrtph.2011.01.006," vol. 3, no. https://doi.org/10.1016/j.yrtph.2011.01.006, pp. 423-429, 2011.

[9] H. R.M, D. A and et.al, "A survey of hallucinogenic mushroom use, factors related to usage, and perceptions of use among college students. Drug and alcohol dependence,", Vols. 130(1-3), pp. 245248, 2013.

[10] A. Wibowo, Y. Rahayu, A. Riyanto and T. Hidayatulloh, "https://scholar.google.co.id/citations?user=Dee3JDoAAAAJ\&hl=id $\& o i=a o \# d=g s$ md citad $\& p=\& u=\% 2 F$ citations $\% 3$ Fview_op\%3Dview citation\%26hl\%3Did\%26user\%3DDee3JDoAAAAJ\%26citation_for _view\%3DDee3JDoAAAAJ\%3AYsMSGLbcyi4C\%26tzom\%3D420," AMIKOM Yogjakarta, 6 Maret 2018. [Online]. [Accessed 3 Setember 2018].

[11] V. N. D. Pratama, Desember 2013. [Online]. Available: https://scholar.google.co.id/scholar?hl=id\&as_sdt=0\%2C5\&q=perilak $\mathrm{u}+\mathrm{remaja} \& \mathrm{btnG}=$.

[12] Sugiono, Metode Penelitian Kuantitatif dan Kualitatif dan R\&D, Bandung: Alfabeta, 2012.

[13] K. S. BPS, "Kota Sukabumi Dalam angka 2017," BadaN Pusat Statistik, Kota Sukabumi, 2017.

[14] Arikunto, Prosedur Penelitian Suatu Pendekatan Praktika, Jakarta: Rineka Cipta, 2006.

[15] M. N. V. Putri, "KEBIJAKAN HUKUM PIDANA DALAM PENANGGULANGAN PENYALAHGUNAAN MAGIC MUSHROOM DIHUBUNGKAN DENGAN UNDANG-UNDANG NOMOR 36 TAHUN 2009 TENTANG KESEHATAN JO 
UNDANG-UNDANG NOMOR 35 TAHUN 2009 TENTANG NARKOTIKA," Institutional Repositorie \& Scientific Journals /http://repository.unpas.ac.id/27381/1/A, 2017. 